\title{
IN VITRO FERTILITY TEST OF HUMAN SPERMATOZOA MEMBRANE PROTEIN FERTILIN BETA ANTIBODY IN MICE (Mus musculus Balb/c) AS IMMUNOCONTRACEPTIVE CANDIDATE
}

\author{
Reny I'tishom ${ }^{1}$, Doddy M. Soebadi ${ }^{2}$, Aucky Hinting ${ }^{1}$, Hamdani Lunardhi $^{1}$, Rina Yudiwati $^{1}$ \\ ${ }^{1}$ Department of Medical Biology, Faculty of Medicine, Universitas Airlangga, Surabaya \\ ${ }^{2}$ Department of Urology, Faculty of Medicine, Universitas Airlangga, Dr Soetomo Hospital, Surabaya
}

\begin{abstract}
ABSTRAK
Salah satu bahan yang potensial sebagai kandidat bahan immunocontraception adalah spermatozoa. Fertilin beta adalah protein membran spermatozoa dan hanya terdapat pada spermatozoa mature serta ejakulat, yang berfungsi sebagai molekul adhesi. Protein membran spermatozoa yang digunakan sebagai kandidat bahan immunocontraception, harus mempunyai kriteria khusus yaitu spesifisitas spermatozoa, peran antigen pada proses fertilisasi, imunogenisitas yang meliputi pembentukan respon antibodi yang cukup berpotensi untuk menghalangi fertilisasi. Antibodi terhadap spermatozoa mempengaruhi tahap sebelum fertilisasi dari proses reproduksi dan dapat menghambat perkembangan zigot setelah fertilisasi. Sampai saat ini sangat sedikit data penelitian protein membran spermatozoa sebagai bahan immunocontraception yang sampai ke uji hewan coba. Tujuan penelitian adalah membuktikan peran antibodi hasil induksi antibodi protein fertilin beta membran spermatozoa manusia dalam merangsang terjadinya aglutinasi dan mereduksi motilitas sehingga menurunkan angka fertilisasi invitro. Penelitian dilaksanakan di Laboratorium IVF, Departemen Biologi Kedokteran Fakultas Kedokteran Universitas Airlangga. Penelitian ini meliputi: Uji potensi antibodi protein fertilin beta membran spermatozoa manusia dan peran antibodinya dalam menghambat proses fertilisasi secara invitro pada mencit (Mus musculus Balb/c). Pada penelitian invitro ini menghasilkan angka fertilisasi sebesar $25 \%$ lebih kecil dibandingkan angka fertilisasi pada kontrol yaitu sebesar 58,7\%, dimana sebelumnya spermatozoa diinkubasi terlebih dahulu dengan antibodi protein fertilin beta membran spermatozoa manusia. Sedangkan persentase daya hambat spermatozoa untuk membuahi oosit sebesar 33,75\%. Potensi imunokontraseptif dianggap efektif apabila terjadi penurunan secara bermakna $(P<0,05)$ dari angka fertilisasi pada kelompok perlakuan dibandingkan dengan kelompok kontrol. Hal ini menunjukkan antibodi protein fertilin beta membran spermatozoa manusia mempunyai kemampuan menghambat untuk membuahi oosit sehingga menurunkan angka fertilisasi. (FMI 2016;52:209213)
\end{abstract}

Kata kunci: antibodi protein fertilin beta membran spermatozoa manusia, fertilisasi invitro, Mus musculus Balb/c

\begin{abstract}
One of the materials as potential candidates immunocontraception material is spermatozoa. Fertilin beta is spermatozoa membrane protein and is found only in mature spermatozoa and ejaculate, which serves as an adhesion molecule. Spermatozoa membrane protein that is used as an ingredient immunocontraception candidate, must have specific criteria that the specificity of spermatozoa, the role of antigen in the fertilization process, which includes the formation of immunogenicity sufficient antibody response has the potential to block fertilization. Antibodies against spermatozoa affect the stages before fertilization of the reproductive process and can hinder the development of the embryo after fertilization. Until now very little research data spermatozoa membrane protein as an ingredient immunocontraception are up to the test of experimental animals. The research objective is to prove the role of the resulting antibody induction of antibodies fertilin beta protein in the membrane of human spermatozoa induce agglutination and reduce motility thus reducing the number of in vitro fertilization. Research conducted at the IVF Laboratory, Department of Biology of Medicine, Faculty of Medicine, University of Airlangga. This research includes: Test the potential of antibody protein beta fertilin membrane of human spermatozoa and inhibit the role of antibodies in vitro fertilization in mice (Mus musculus Balb/c). In vitro studies have resulted in fertilization figure of $25 \%$ is smaller than the number that is equal to control fertilization of $58.7 \%$, whereas previously the spermatozoa were incubated first with a beta membrane protein antibody fertilin human spermatozoa. While the percentage of inhibition of sperm to fertilize an oocyte by 33.75\%. Potential imunokontraseptif considered effective if it decreased significantly $(P<0.05)$ than the numbers fertilization in the treatment group compared with the control group. This shows fertilin beta membrane protein antibody has the ability to inhibit human spermatozoa to fertilize oocytes that reduce the number of fertilization.(FMI 2016;52:209-213)
\end{abstract}

Keywords: beta membrane protein antibody fertilin human spermatozoa, fertilization invitro, Mus musculus Balb/c

Correspondence: Reny I'tishom, Department of Medical Biology, Faculty of Medicine, Universitas Airlangga, Surabaya. e-mail: ishom.fkua@gmail.com 


\section{INTRODUCTION}

Barriers spermatozoa membrane protein interaction with glycoprotein zona pellucida (ZP3), or the mechanism of fusion with the cell membrane of eggs using the principle of antigen-antibody, is the basis immunocontraception (Griffin 2003). Spermatozoa membrane proteins that act as antigens and immunogenic, allowing the induction of anti-specific protein molecules. In the development of materials immunocontraception, the necessary exploration and characterization of membrane proteins spermatozoa specific mainly acts as an antigen is immunogenic, specific, engaging interaction with zona pellucida (ZP3) and fusion with oocytes (Naz 2006) so as to help create a candidate material immunocontraception ideal nature anti spermatozoa (Bohring \& Krause 2003). Immunization with material immunogen in an individual is expected to produce a humoral immune response in the form of antibodies. Antibodies can prevent conception directly (Martinez \& Harris 2000). Darsini et al (2012), have managed to synthesize beta fertilin polyclonal antibody protein membrane of human spermatozoa and prove fertilin beta protein is immunogenic in rabbits.

One of the materials as potential candidates immunocontraception material is spermatozoa. I'tishom et al (2013), has succeeded in isolating and characterizing protein beta fertilin membrane of human spermatozoa. Naz (1996), states spermatozoa development as a vaccine antigen in immuno-contraception based on two reasons: 1) immunization in animals female and male animals, and in humans with mature spermatozoa resulting in infertility. Infertility is caused by the death of preimplantation embryo, and 2) the occurrence of spontaneous infertility $(70 \%$ of men with vasectomy develop antibodies to spermatozoa in both men and women). According Domagala and Kurpisz (2004), antibodies to the sperm before fertilization affects the phase of the reproduction process (agglutination and immobilization of spermatozoa, spermoocyte interaction) and to inhibit the development of the zygote after fertilization. However, until now very little research data spermatozoa membrane protein as an ingredient immunocontraception are up to the test of experimental animals.

One of the spermatozoa membrane proteins that have this potential is fertilin beta. Fertilin beta is only available on ejaculated spermatozoa mature and functioning as adhesion molecules. According to Naz et al (2005), a membrane protein spermatozoa were used as candidate materials immunocontraception, must have specific criteria that specificity spermatozoa (only work on gametes and not to other organs), the role of antigen in the process of fertilization, immunogenicity which includes the formation of antibody responses potent enough to block fertilization.

\section{MATERIALS AND METHODS}

\section{Research design}

This study design was exploratory laboratory which analyzed by descriptive and statistical analysis. This study aims to determine the ability of spermatozoa in vitro fertilization to test animals injected the antibody protein beta fertilin membrane of human spermatozoa in infertility test, so that these antibodies can be developed as a candidate material immunocontraception effective, safe, efficient and reversible. This study had previously received approval from the Committee on bioethics and Humanities Faculty of Medicine, University of Airlangga. Research conducted at the IVF Laboratory, Department of Biology of Medicine, Faculty of Medicine, University of Airlangga.

\section{Material}

Semen of male mice and oocytes of female mice, aqua for injection, PMSG, hCG, phosphate buffered saline (PBS), sterile distilled water, TCM-199, mineral oil (Sigma), deionized water (PT. Otsuka-Lawang), the culture medium, alcohol ,

\section{Tool}

Light microscopes, stereo microscopes, hand counter, timer, tip, object-glass, cover glass, CO2 incubators, laminar flow, $\mathrm{CO} 2$ cylinders, refrigerator, a set of glassware, analytical balance brands METTLER AE-50, eppendorf, vortex, test tubes, aluminum foil, shaker, micro pipette $1-100 \mathrm{~mL}, 1 \mathrm{~mL}$ syringe, pipette $10 \mathrm{ml}$, pasteur pipette, petri dish, tweezers, scissors.

Potential Test fertilin beta protein antibody in inhibiting membrane of human spermatozoa in vitro fertilization performed. Serum antibody derived from immunization results. While the mice used were mice were fertile. Spermatozoa collected from the cauda epididymis with a concentration of $2 \times 106$ cells/100? L. Capacitation of spermatozoa done on $\mathrm{CO} 2$ incubator at a temperature of 350C for one hour. In vitro studies conducted through binding assays and test fertilization (Wahyuningsih 2011).

\section{Data analysis}

Qualitative data descriptively narrated. Quantitative data were analyzed with statistical test $(\mathrm{a}=0.05)$, is used for invitro fertilization test analysis. Prior to the statistical 
test, all the data were tested for normality of distribution and homogenisitas variants. Normal distribution of data and homogeneous bervarian tested by analysis of variance one direction and continued test of Duncan. Normal distribution of data, the variance is not homogeneous tested with Brown-Forsythe followed by Kruskal-Wallis and Mann-Whitney test was continued.

\section{RESULTS}

\section{Invitro Fertilisation test Fertilin Beta Protein Antibodies Human Sperm Membrane in Animals Try mice (Mus musculus Balb/c)}

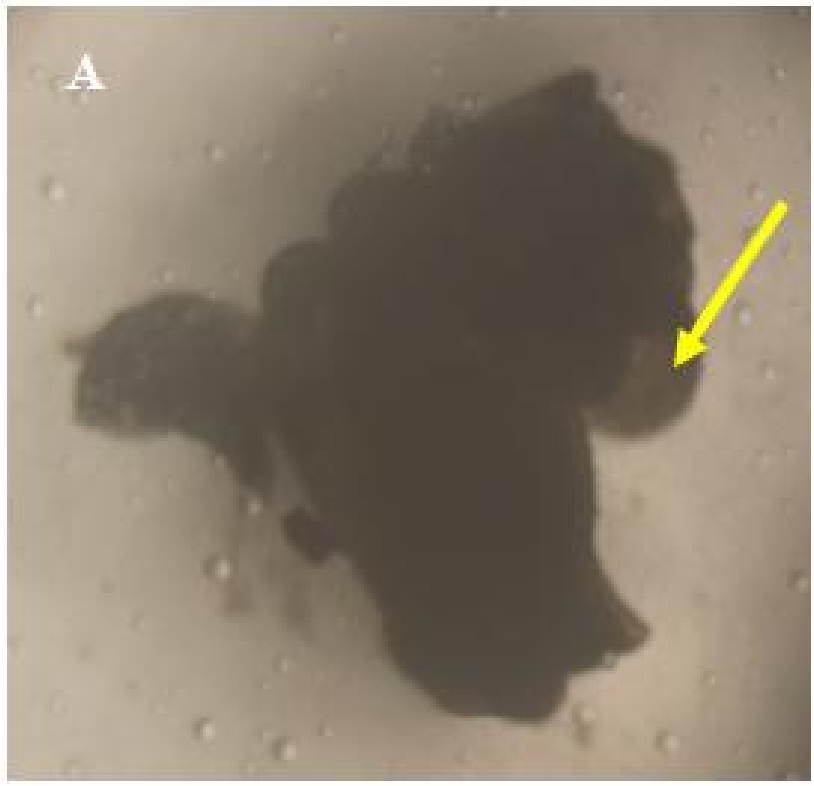

Invitro fertilization trials aimed to prove that the protein beta fertilin membrane of human spermatozoa could hamper the ability of sperm to fertilize oocytes in mice (Mus musculus Balb/c) to the invitro fertilization. Parameters measured were oocytes have cleavage after fertilized. Total sigot splitting can be seen in Table 1 .

Motile spermatozoa obtained from cauda epididymis of mice with the way in flushing. Results have motility of spermatozoa collection of $100 \%$ for all motile. Spermatozoa concentration of about 1 million per $1 \mathrm{ml}$ of the medium. Oocytes collected from ampulla tuba. Ampulla tuba opened with a tuberculin needle. Ampulla tuba and oviduct can be seen in Figure 1.

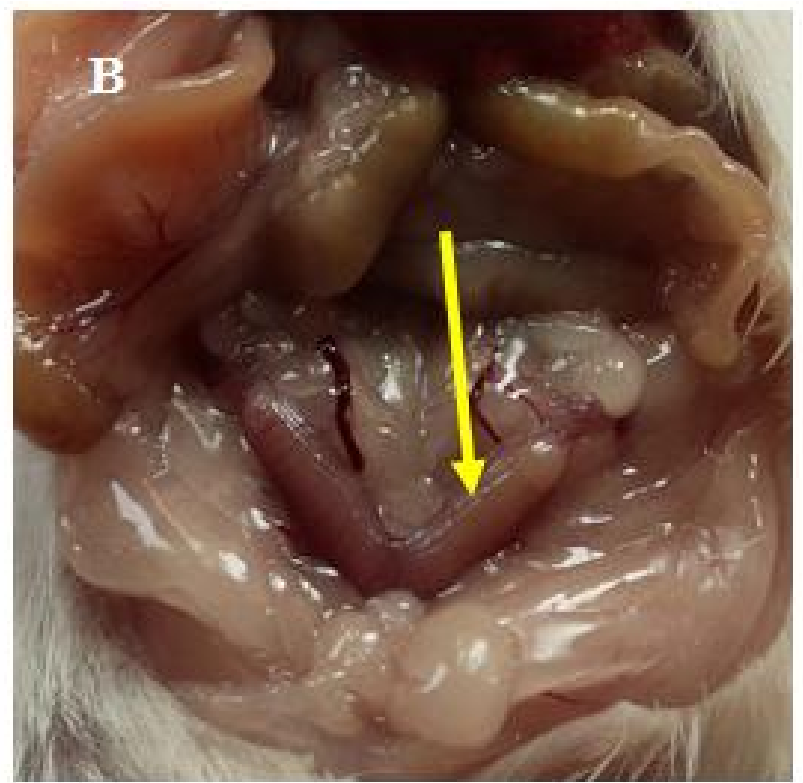

Fig. 1. (A) ampulla tuba with a stereo microscope observation magnification of $400 \mathrm{X}$ and (B) oviduct

The existence seemed ripe oocytes from cumulus bloom and surround it consists of more than 5 layers. Spermatozoa collected from the cauda epididymis of mice were incubated with antibody beta protein membrane of human spermatozoa with concentrations of $10 \mathrm{ug} / \mathrm{ml}$. Spermatozoa were incubated for 30 minutes at a $\mathrm{CO} 2$ incubator, and then used to fertilize oocytes that had been harvested. After 5-7 hours oocytes that mixes with sperm transferred to the culture medium. The next day began observations of how oocytes were fertilized and divide. Oocytes were mature and the results of in vitro fertilization (IVF) can be seen in Figure 2.

From the Kolmogorov-Smirnov test was obtained significance level $\mathrm{P}=0.000$ smaller than? $=0.05$. This indicates that the data obtained bersistribusi not normal. Furthermore, data on the number of oocytes fertilized analyzed with non-parametric Kruskal-Wallis. Based on the test results indicate that the influence of the membrane protein immunization of human spermatozoa in vitro fertilization in experimental animals mice.

In the group treated with antibody incubation fertilin beta protein has a $25 \%$ fertilization figure significantly different from the control group is $58.7 \%$. This shows that there is influence of incubation of spermatozoa in antibodies against beta fertilin membrane protein on the ability of human spermatozoa to fertilize oocytes. On the control bit occurs inhibition of fertilization that is equal to $41.5 \%$, while in treatment by $75 \%$. 
Table 1. Figures fertilization $(\%)$ of the results of in vitro fertilization between the sperm of mice were incubated with antibody proteins of human spermatozoa with the oocyte membrane

\begin{tabular}{cccc}
\hline Repetition & $\begin{array}{c}\text { Total } \\
\text { Oocyte }\end{array}$ & \multicolumn{2}{c}{ Fertilization Number (\%) } \\
\cline { 3 - 4 } & & Control & $\begin{array}{c}\text { Treatment with } \\
\text { beta fertilin } \\
\text { antibody }\end{array}$ \\
\hline 1 & 10 & 6 & 3 \\
2 & 10 & 6 & 3 \\
3 & 10 & 5 & 2 \\
4 & 10 & 7 & 3 \\
5 & 10 & 4 & 2 \\
6 & 10 & 8 & 1 \\
7 & 10 & 5 & 4 \\
8 & 10 & 6 & 2 \\
\hline Mean \pm & & $58.7^{\mathrm{a}}$ & $25^{\mathrm{b}}$ \\
SD & & 1,528 & 2,000 \\
\hline
\end{tabular}

Description: The same Superscript showed no significant difference $(\alpha$ $=0.05)$
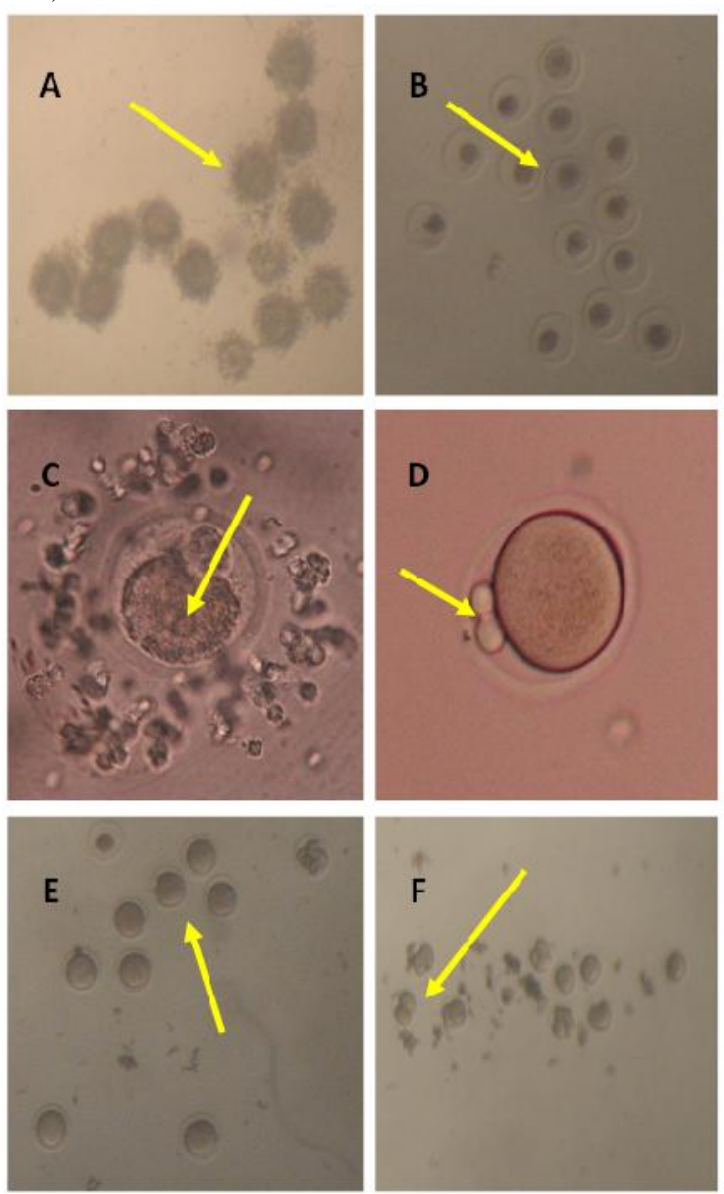

Fig. 2. Results of in vitro fertilization (IVF). (A) oocytes with cumulus, (B) oocytes degeneration, (C) Pronuclei, (D) Polar body II, (E) Treatment (spermatozoa incubation with antibody induction results fertilin beta), (F) Control without any antibody.

\section{DISCUSSION}

\section{Invitro Fertilisation test Fertilin Beta Protein Antibodies Human Sperm Membrane in Animals Try mice (Mus musculus Balb/c)}

In vitro fertilization test showed spermatozoa to the oocyte fusion barriers. It can be used as the basis for subsequent in vivo test, so it can be the role of beta membrane protein antibody fertilin spermatozoa on fertility and can also show how far the reversibility of antibody protein beta fertilin so it can be considered as material immunocontraception.

Invitro fertilization is the process of unification of male and female gametes. IVF requires almost the same conditions that exist in the body. The environmental conditions need to be well prepared, medium, temperature, the incubator should be in prime condition for support of fertilization. The addition of the medium will also affect the success of fertilization. Giving the combination of glucose and phosphate in the culture medium in vitro results were better embryo development to the blastocyst stage. Glucose is needed as a source of energy for cell metabolism (Widjiati et al, 2011). Oocytes and spermatozoa conditions are optimal also affect fertilization. Spermatozoa will fertilize oocytes after undergoing a process of capacitation, spermatozoa become more active and have more rapid motility to fertilize oocytes. Spermatozoa also had to undergo the acrosome reaction by removing the enzyme in the head to be able to penetrate the oocyte. Fusion occurs after the sperm penetrates the zona pellucida, the sperm will fuse with the cytoplasmic membrane. Fertilization failure can be caused by the failure of sperm fusion with the cytoplasmic membrane despite already successfully passed through the zona pellucida (Faizah 2013).

Although oocytes are very large cells, but the spermatozoa are not free to access. A layer of extracellular and heterogeneous organization of oocytes limit the number of spermatozoa that can reach the surface of the oocyte. Before interacting with the zona pellucida, the sperm must traverse and interact with the outside of the oocyte. In mammals have a layer of jelly, follicular cells and cumulus cells. All these layers drastically reduced the number of spermatozoa that will reach the zona pellucida (Elder \& Dale 2000).

In this study, the results of fertilization in vitro fertilization to produce numbers by $25 \%$ smaller than the numbers fertilization on the control that is equal to $58.7 \%$, whereas previously the spermatozoa were incubated first with a beta membrane protein antibody fertilin human spermatozoa. While the percentage of inhibition 
of sperm to fertilize an oocyte by $33.75 \%$. Potential imunokontraseptif considered effective if it decreased significantly $(\mathrm{P}<0.05)$ than the numbers fertilization in the treatment group compared with the control group. This shows fertilin beta membrane protein antibody has the ability to inhibit human spermatozoa to fertilize oocytes that reduce the number of fertilization.

A material effect as antifertilitas when the statistics for more than $60 \%$ of infertility or a fertility rate of $40 \%$ (Lee \& Chi 1985). Other studies using rabbit polyclonal antibody to incubate at cattle spermatozoa in vitro fertilization to produce numbers fertilization by $63 \%$ in the control group and $17 \%$ in the treatment group (Ramalho-Santos et al 2000). Research antibodies against spermatozoa murine protein induced in mice spermatozoa it produces cleavage embryos of $4.8 \%$ (Naz \& Zhu 1998).

Calamera et al (2002) stated that the presence of antibodies to spermatozoa can inhibit recognition in the zona pellucida and the fusion of gametes. Reduction of motility in the penetration of the zona pellucida will inhibit sperm oocyte fusion related directly to the presence of antibodies against the inner acrosomal membrane (Mayonda 2006). Binding of anti sperm antibodies (ASA) on a specific antigen spermatozoa involved in the fertilization process is often used as an ingredient immunocontraception (Bohring et al 2001).

\section{CONCLUSION}

Fertilin beta antibody protein membrane of human spermatozoa can inhibit the ability of sperm to fertilize an oocyte, thereby reducing the number of in vitro fertilization in mice.

\section{REFERENCES}

Bohring,C.,Krause,E.,Habermann,B.,Krause,W. 2001. Isolation and identification of sperm membrane antigens recognized by antisperm antibodies, and their possible role in immunological infertility disease. Mol Hum Reprod. 7: 113-118

Calamera JC.,GF Doncel.,S brugo-Olmedo.,A Sayago and AA Acosta.2002. Male antisperm antibodies:association with a modified sperm stress test and lipid peroxidation. Andrologia, 34(2):63-68.

Darsini N., Lunardhi H.,Aswin RH.,I'tishom R., Hinting A. 2012. Synthesis of beta fertilin protein polyclonal antibody of human sperm membrane as a candidat for immunocontraceptive material. Folia Medica Indonesiana Vol. 48, No. 1. Januari-March 2012: 611.

Domagala A. and M. Kurpisz. 2004. Identification of sperm immunoreactive antigen for immunocontraceptive purposes: A review. Reproductive Biology and Endocrinology, 2: 11-18.

Elder K and Dale B. 2000. In vitro fertilization. 2nd edition. Cambridge University Press.

Faizah, Z. 2013. Perbandingan maturasi, morfologi dan fertilisasi antara oosit sapi yang divitrifikasi pra dan pasca maturasi invitro. Program Pascasarjana. Universitas Airlangga Surabaya. Tesis. (Tidak dipublikasikan).

Griffin, P.D. 2003. Contraceptive Vaccine. Special Programme of Research. Development and Research Training in Human Reproduction. WHO. 1211 Geneva Switzerland.

I'tishom R., Soebadi DM., Hinting A.,Lestari U. 2013. Characterization of fertilin beta protein of human sperm a candidate for immunocontracetion. Folia Medica Indonesiana. Volume 49, Nomer 1,Hal 26-32.

Martinez ML and Harris JD.2000. effectiveness of zona pellucida protein $\mathrm{ZPB}$ as an immunocontraceptive antigen. Journal of Reproduction and Fetility, 120:1932.

Mayonda IT.,2006. The Immunology of human reproduction. Taylor \& Francis Group. London.

Naz R.K. 1996. Application of sperm antigen in immunocontraception. Frontier in Bioscience 1, e8795, September 1, 1996.

Naz RK, Zhu X. 1998. Recombinant fertilization antigen-1 causes a contraceptive effect in actively immunized mice. Biol Reprod 1998, 59:1095-1100.

Naz RK. 2006. Antisperm immunity for contraception. Journal of Andrology. 27:153-159.

Ramalho-Santos J, Ricardo D.M, Sutovsky P., A WingSang Chan, Hewitson L., Gary M.W., Simerly CR., Schatten G. 2000. SNAREs in mammalian sperm: possible implications for fertilization. Developmental Biology, 223: 54-69.

Wahyuningsih, S.P.A. 2011. Analisis potensi protein subunit membran spermatozoa kelinci sebagai kandidat bahan immunocontraception. PPs Universitas Airlangga. Surabaya. Disertasi. Tidak dipublikasikan.

Widjiati, Sukra Y., Purwantara B., Djuwita I. 2011. The role of glucose and phosphate in vitro culture medium to overcome cell block on mouse embryo. Folia Medica Indonesiana Vol. 47 No. 3 July - September 2011: 166-170. 